\title{
MODEL KIRKPATRICK DALAM EVALUASI PROGRAM PELATIHAN KEPEMIMPINAN TINGKAT IV
}

\author{
Alamsyahril \\ Badan Kepegawaian dan Sumber Daya Manusia Kota Lubuk Linggau \\ Article history \\ Received: 7 Agustus 2020 \\ Revised : 14 Agustus 2020 \\ Accepted : 21 Agustus 2020 \\ ${ }^{*}$ Corresponding author \\ Alamsyahril \\ Email : coachariel04@gmail.com
}

\begin{abstract}
Abstrak
Setelah penyelenggaraan suatu pelatihan, perlu adanya evaluasi program pelatihan karena hasil evaluasi akan memberikan umpan balik bagi perbaikan program pelatihan selanjutnya. Penelitian evaluasi ini bertujuan untuk mengidentifikasi efektivitas program pelatihan kepemimpinan tingkat IV bagi pejabat pengawas yang diselenggarakan oleh Badan Kepegawaian dan Pengembangan Sumber daya Manusia Kota Lubuklinggau. Model Kirkpatrick digunakan untuk mengidentifikasi hasil reaction, learning, behavior, dan result. Hasil temuan ini menyebutkan bahwa model kirkpartrick efektif memecahkan masalah program pelatihan kepemimpinan dengan hasil sempurna.
\end{abstract}

Keywords: evaluasi, pelatihan kepemimpinan, Model Kirkpatrick

\begin{abstract}
After organizing training, it is necessary to evaluate the training program because the results of the evaluation will provide feedback for the improvement of the next training program. In this evaluation research we identified the effectiveness of the Leadership Training Program for supervisory officials organized by the Staffing and Human Resources Development Agency. The Kirkpatrick's model was used to identify reaction, learning, behavior, and results. The analysis using this model state that the participants have shown positive reactions to lecturers and coaches, the learning process has shown the success of the distribution of the value of the graduation of participants in which most of participants graduated with satisfactory qualifications, and there were some behavior changes of Leadership Training alumni. They stated that the training can support the implementation of their papers in the mid and long term.
\end{abstract}

Keywords: Evaluation, Leadership Training, Kirkpatrick's Model

(c) 2020 Pusdiklat Perdagangan. All rights reserved

\section{PENDAHULUAN}

Pengembangan kompetensi asn dapat dilakukan melalui berbagai cara, salah satunya melalui pelatihan. Pelatihan bagi Aparatur Sipil Negara (ASN) ini terbagi atas pelatihan pra jabatan dan pelatihan dalam jabatan (PP
Nomor 101 tahun 2000). Salah satu bentuk pelatihan dalam jabatan adalah pelatihan kepemimpinan baik itu untuk jabatan pengawas, jabatan administrator, maupun jabatan pimpinan tinggi. Pelatihan kepemimpinan ini diselenggarakan oleh 
lembaga pelatihan yang terakreditasi termasuk Unit Pelaksana Teknis Pendidikan dan Pelatihan (UPT Pelatihan) yang bernaung di bawah Badan Kepegawaian dan Sumber Daya Manusia (BKPSDM) Kota Lubuklinggau yang sudah terakrediatsi untuk pelatihan kepemimpinan bagi pejabat pengawas dan pejabat administrator.

Akan tetapi selama pelaksanaan pelatihan kepemimpinan baik itu bagi jabatan pengawas maupun bagi jabatan administrator jarang sekali dilakukan evaluasi program pelatihan di UPT ini. Padahal, setiap selesai pelaksanaan pelatihan seharusnya diadakan evaluasi program agar kelebihan dan kekurangan dalam program tersebut dapat diidentifikasi sehingga perbaikan dapat ditindaklanjuti (Rouse, 2011). Melalui evalusi ini maka dapat diketahui bagaimana kualitas proses pelatihan itu sendiri dan juga perubahan kinerja peserta pelatihan di tempat kerja nya masing masing. Hal tersebut sesuai dengan fungsi evaluasi yang dikemukakan Badu, (2013) yaitu untuk memperoleh informasi yang akurat dan objektif pada sebuah program, yang telah direncanakan dan diimplementasikan pada fase sebelumnya. Informasi tersebut dapat berupa proses pelaksanaan program, dampak/hasil yang dicapai, efisiensi.Jadi, evaluasi menjadi sangat penting untuk dilakukan karena evaluasi akan mengukur tingkat ketercapaian dari program pelatihan yang dilakukan sehingga akan memberikan feed back untuk kelangsungan program pelatihan selanjutnya. Hasil evaluasi dapat juga dijadikan tolak ukur apakah program tersebut berhasil atau tidak, dapat dilanjutkan atau dihentikan, serta dapat dijadikan pijakan untuk menyusun program lanjutan.

Menurut Kirkpatrick, D.,L. \& Kirkpatrick J.,D. (2006) adalah untuk menentukan tingkat efektifitas dari suatu program pelatihan, sehingga ketika kegiatan evaluasi sudah dilakukan diharapkan dapat menjadi dasar bagi pihak-pihak yang bertanggung jawab dalam program tersebut, dalam membuat keputusan berdasarkan hasil evaluasi. Dalam melaksanakan kegiatan evaluasi tersebut, tentunya diperlukan suatu model evaluasi yang mampu melakukan penilaian terhadap kualitas dan efektifitas pelaksanaan dari suatu program pelatihan.
Salah satu model evaluasi adalah Model Kirkpatrick yang dikembangkan oleh Kirkpatrick yang dikenal dengan istilah Kirkpatrick Four Levels Evaluation Model. Keempat level tersebut adalah: Level 1 - Reaction (Reaksi), Level 2 - Learning (Pembelajaran), Level 3 Behavior (Perilaku), dan Level 4 - Results (Hasil/Dampak). Model evaluasi digunakan untuk mengevaluasi program pelatihan (Ananda dan Rafida, 2017).

Model Kirkpatrick inilah yang saya terapkan dalam mengevaluasi program Pelatihan Kepemimpinan Tingkat IV Angkatan $V$ yang diselenggarakan di UPT Pelatihan Kota Lubuklinggau pada tahun 2018

\section{METODOLOGI}

Model evaluasi yang digunakan dalam penelitian ini adalah Model empat level Kirkpatrick, yang terdiri dari Reaction, Learning, Behavior, dan Result. Evaluating reaction atau mengevaluasi terhadap reaksi peserta pelatihan adalah aktivitas mengukur kepuasan peserta (customer satisfaction) terhadap program pelatihan yang dilaksanakan. Evaluating learning ini disebut juga penilaian hasil (output) belajar. Penilaian tingkah laku pada evaluating behaviour difokuskan pada perubahan tingkah laku setelah peserta pelatihan kembali ke tempat kerjanya. Evaluating result atau evaluasi hasil difokuskan pada hasil akhir (final result) yang terjadi karena peserta pelatihan telah mengikuti suatu program pelatihan

\section{HASIL DAN PEMBAHASAN}

Penelitian ini menggunakan Model Evaluasi 4 level yang dikembangkan oleh Donald Kirkpatrick yang terdiri dari reaction, learning, behavior dan result. Jadi hasil penelitian dalam hal ini juga dikelompokkan dalam 4 level tersebut.

\section{Reaction}

Dalam Reaction ini akan dibahas hasil dari kuesioner dari evaluasi terhadap tenaga pengajar / widyaiswara oleh peserta pelatihan, evaluasi terhadap tenaga pengajar / widyaiswara oleh tim evaluasi, evaluasi 
pelaksanaan pelatihan oleh peserta pelatihan, dan evaluasi terhadap coach oleh peserta.

Nilai rata-rata dari evaluasi peserta terhadap tenaga pengajar/widyaiswara adalah berata di atas nilai 80. Kalau dikonversi ke tabel rentang penilaian maka rata-rata menunjukkan predikat sangat memuaskan. Tim evaluasi tenaga pengajar/widyaiswara terdiri dari Kepala BKPSDM Kota Lubuklinggau, Kepala UPT, Koordinator Widyaiswara, dan Kepala TU UPT Pelatihan Berbeda dengan hasil penilaian tenaga pengajar/widyaiswara yang dilakukan oleh peserta, penilaian yang dilakukan oleh tim evaluasi menunjukkan bahwa rata-rata nilai tenaga pengajar/widyaiswara berada dalam predikat memuaskan dengan rentang nilai rata-rata dari 76.60 sampai dengan 81.43.

Ada lima unsur pelaksanaan pelatihan yang dievaluasi oleh peserta diakhir pelaksanaan pelatihan, yaitu metode dan media, relevansi, manfaat/efektifitas, fasilitas pelatihan, dan konsumsi. Dari chart di atas maka diketahui bahwa Manfaat/Efektifitas dan Relevansi berada pada predikat Memuaskan sedangkan konsumsi berada pada predikat Kurang Memuaskan.

Hasil dari kuesioner penilaian tenaga pengajar / widyaiswara oleh peserta menunjukkan bahwa secara umum tenaga pengajar / widyaiswara yang memberikan materi pelatihan pada Pelatihan Kepemimpinan Tingkat IV angkatan V tahun 2018 sudah sangat memuaskan. Akan tetapi jika dilihat per item dari kuesioner tersebut, item 7 yang menunjukkan nilai rata rata terendah, yaitu kesempatan tanya jawab. Selain dari rata rata nilai, kurangnya kesempatan tanya jawab ini menjadi fokus beberapa peserta dalam mengisi pendapat dan saran di kuesioner tersebut. Hal ini mengindikasikan bahwa tenaga pengajar/widyaiswara masih penggunakan pendekatan pedagogi dalam proses pembelajaran. Padahal dalam proses pembelajaran pelatihan, tenaga pengajar / widyaiswara sebaiknya menggunakan pendekatan andragogi, yaitu pembelajaran orang dewasa. Karena peserta pelatihan telah mempunyai pengetahuan sebelumnya, maka sebaiknya tenaga pengajar/widyaiswara memberbanyak sesi knowledge sharing baik antara tenaga pengajar/widyaiswara dengan peserta maupun sesama peserta.

Sebaliknya ada item yang mendapatkan nilai rata rata tertinggi, yaitu item nomor 1 penguasaan materi. Tenaga pengajar/widyaiswara yang menyampaikan materi pada Pelatihan Kepemimpinan Tingkat IV angkatan $V$ sudah menunjukkan penguasaan materi yang baik dalam proses pembelajarannya. Walaupun tenaga pengajar/widyaiswara ini dari latar belakang pendidikan yang beragam dan punya pengalaman yang berbeda-beda, mereka sudah menunjukkan kemampuan mereka dalam penguasaan materi yang disampaikan selama proses pembelajaran.

Selanjutnya hasil kuesioner tentang penilaian tenaga pengajar/widyaiswara yang diisi oleh tim evaluasi menunjukkan bahwa secara umum dari 16 orang tenaga pengajar/widyaiswara yang memberikan materi pada Pelatihan Kepemimpinan Tingkat IV angkatan V ini, ada 4 orang yang mendapatkan predikat sangat memuaskan dengan rincian 1 orang dari BKPSDM Kota Lubuklinggau, 2 orang dari Lembaga Administarsi negara, dan 1 orang dari Pemkot Lubuklinggau. Jadi perlu pembinaan lagi dari pihak yang berkompeten kepada para widyaiswara dalam persiapan, pelaksanaan, dan evaluasi proses pembelajaran pelatihan. Berdasarkan hasil rekapitulasi penilaian tenaga pengajar/widyaiswara oleh tim evaluasi, hal hal yang perlu mendapatan penekanan dalam pembinaan widyaiswara adalah kompetensi substantif dengan sub kompetensi kemampuan dalam menulis karya ilmiah yang terkait dengan lingkup kepelatihanan dan/atau pengembangan spesialisasi. Banyak widyaiswara terutama widyaiswara dari BKPSDM Kota Lubuklinggau belum memiliki kemampuan yang mumpuni dalam menulis karya tulis ilmiah, padahal hal tersebut merupakan salah satu hal wajib yang harus dipenuhi ketika mereka mengajukan usul kenaikan pangkat.

Akan tetapi hasil dari kuesioner ini menunjukkan bahwa item yang memiliki rata rata tertinggi adalah kompetensi substantif dengan sub 
kompetensi kemampuan dalam menguasai keilmuan dan keterampilan mempraktikkan sesuai dengan materi pelatihan yang diajarkan. Kalau kita kembali ke hasil kuesioner yang diisi oleh peserta sepertinya ada sinergitas antar kedua nilai rata rata ini, yaitu penguasaan materi. Hal ini menandakan bahwa dari segi kredibilitas keilmuan, para widyaiswara di BKPSDM Kota Lubuklinggau sudah cukup mumpuni.

Dari evaluasi pelaksanaan pelatihan yang dilakukan oleh peserta, yang menjadi sorotan adalah item yang menyangkut konsumsi yaitu yang berhubungan dengan pengaturan waktu snack, variasi snack, variasi makan siang dan makan malam, variasi sarapan pagi, pelayanan dan sikap petugas catering, dan kebersihan ruang makan. Pada saran saran yang diisi peserta di lembar kuesioner, terlihat memang masalah konsumsi menjadi sorotan. Misalnya, ada yang menulis "khusus untuk konsumsi perlu segera dilakukan perubahan yang disesuaikan dengan kondisi peserta', 'hendaknya dalam penyediaan konsumsi jangan sampai kekurangan', snack dan makan, baik makan malam makan siang mauppun sarapan pagi sangat tidak bervariasi dan sangat kurang dari segi rasa dan menu, mohon diperbaiki untuk yang akan datang'. Dari contoh saran saran ini dan juga saran saran lainnya, dapat dikatakan bahwa reaksi peserta terhadap konsumsi yang diberikan oleh penyelenggara kurang memuaskan.

Namun peserta menunjukkan reaksi positif terhadap manfaat/efektivitas dan relevansi dengan nilai rata rata tertinggi untuk kedua item ini. Artinya peserta merasakan manfaat yang didapat selama pelatihan dalam pelaksanaan tugasnya di instansi nya masing masing. Dan juga peserta merasakan bahwa materi yang diberikan selama pelatihan ada relevansi nya dengan pekerjaan mereka sehari hari di tempat tugas. Materi yang diberikan bisa diaplikasikan dalam pelaksanaan pekerjaan mereka.

Terakhir adalah reaksi peserta terhadap coach. Sebagaimana dijelaskan sebelumnya bahwa selama mengikuti Pelatihan Kepemimpinan Tingkat IV, peserta didampingi oleh mentor dan coach. Mentor merupakan atasan langsung peserta di tempat kerja, sedangkan coach adalah widyaiswara di lembaga pelatihan. Mentor dan coach ini yang mendampingi peserta pelatihan dalam penulisan proyek perubahan. Di akhir penyelenggaraan pelatihan, peserta diminta untuk memberikan evaluasi terhadap coach. Ada 5 orang widyaiswara yang bertugas sebagai coach pada Pelatihan Kepemimpinan Tingkat IV angkatan $V$ ini. Dari hasil kuesioner dapat diketahui bahwa 2 orang coach yang mendapatkan predikat dengan pujian dan 3 orang coach mendapatkan predikat sangat memuaskan. Ini menandakan bahwa semua coach di Pelatihan Kepemimpinan Tingkat IV angkatan $V$ ini telah menjalankan tugas nya dengan baik. Dari item item yang ada dalam kuesioner dan dari analisisnya maka dapat diketahui bahwa para coach masih perlu untuk memperbaiki 3 hal, yaitu Kemampuan mengarahkan sistematika penulisan laporan, Kemampuan menyampaikan substansi materi, dan Penggunaan metode dan media bantu dalam penullisan laporan baik dalam proses pembimbingan maupun dalam mengarahkan peserta.

Dari hasil wawancara dengan coach, untuk point pertama ternyata para coach mempunyai sistematika penulisan laporan tersendiri. Sesuai dengan arahan dan petunjuk dari LAN dan juga dari materi di modul Pelatihan Kepemimpinan Tingkat IV, tidak ada sistematika laporan yang baku, para coach bebas berkreasi membuat sistematika sendiri. Ternyata hal ini membingunkan para peserta. Para coach juga masih perlu memperbaiki kemampuan menyampaikan substansi materi. Para peserta berasal dari berbagai instansi dengan berbagai tugas pokok dan fungsi nya serta dengan berbagai latar belakang pendidikan. Para coach punya keterbatasn pengetahuan tentang dunia kerja nya para peserta, ini yang menjadi kendala bagi coach saat menyampaikan substansi materi laporan proyek perubahan. Sebenarnya inilah peran mentor saat mendampingi peserta. Pembagian tugas nya jelas, mentor membimbing dari segi substansi dan coach membimbing pada metodologi. Hal ketiga yang perlu diperbaiki para coach dari hasil 
kuesioner yang diisi peserta adalah penggunaan metode dan media. Dalam memberikan pendampingan, para coach melakukannya secara individual sehingga jarang sekali menggunakan media seperti LCD atau powerpoint. Karena pendampingan dilaksanakan secara indvidu, maka para coach juga diharapkan memberikan bimbingan sesuai dengan karakteristik individu dari masing masing peserta yang menjadi bimbingannya

\section{Learning}

Ada dua instrumen yang dibahas dalam learning, yaitu hasil dari kuesioner Evaluasi Kepemimpinan Oleh Peserta dan Dokumentasi Keberhasilan Peserta Pelatihan Kepemimpinan Tingkat IV. Dalam evaluasi kepemimpinan oleh peserta, peserta diminta untuk mengisi kuesioner terbuka dimana mereka diminta untuk menuliskan pengalaman mereka selama pengikuti Pelatihan PIM IV dan pengalaman mereka dalam memimpin proyek perubahan. Berikut adalah beberapa catatan peserta:

Peserta 1 menyatakan bahwa Di dalam Pelatihan Kepemimpinan Pola Baru ini, kami banyak mendapatkan ilmu yang bermanfaat bagi saya dan untuk diterapkan di dinas instansi saya, yang selama ini instansi saya belum ada inovasi, Insya Allah dengan selesainya pelatihan ini, maka saya bisa meneruskan implementasi proyek perubahan ini di jangka menengah dan jangka panjang. Banyak pengalaman yang kami dapatkan selama pelatihan kepemimpinan ini seperti kedisiplinan, tata kerja yang baik dan etika terhadap pelayanan dengan masyarakat

Peserta 2 menyatakan bahwa dalam memimpin proyek perubahan saya, ada beberapa pengalaman menarik seperti kerjasama antar tim baik, masih ada kendala dalam kerjasama lintas sektoral, dukungan lintas sektoral perlu ditingkatkan, perlu dibuat tahapan kegiatan yang baik, untuk mempengaruhi atasan perlu menerapkan kedekatan emosional dan profesional.

Peserta 3 menyatakan bahwa Pelatihan Kepemimpinan Tingkat IV Angkatan $\mathrm{V}$ Tahun
2018 di BKPSDM Kota Lubuklinggau dengan pola baru melahirkan pemimpin perubahan. Salah satu pembelajarannya adalah belajar dari diri sendiri menilai sejauh mana keberhasilan dalam memimpin perubahan dan belajar dari pengalaman orang lain yang sudah berhasil. Dalam laboratorium kepemimpinan ini leader harus beradaptasi dan mengimplementasikan cara-cara terbaik dalam memimpin suatu perubahan.

Peserta 4 menyatakan bahwa proyek perubahan wadah untuk membuktikan jiwa kepemimpinan yang mencakup ketajaman mendiagnosa permasalahan, menentukan langkah langkah yang tepat untuk membawa perubahan dengan cara berkoordinasi dan berkolaborasi mengatasi permasalah di organisasi serta mencari solusi untuk mengatasi kendala kendala pelaksanaan proyek perubahan sehingga resiko resiko tidak terjadi.

Keberhasilan peserta pelatihan dilihat dari nilai akhir yang dicapai mereka setelah mengikuti Pelatihan Kepemimpinan Tingkat IV. Ada 2 kali pelaksanaan penilaian, yaitu penilaian Perencanaan Inovasi melalui Seminar Rancangan Proyek Perubahan dan penilaian Manajemen Perubahan melalui Seminar Laboratorium Kepemimpinan. Peserta Pelatihan Kepemimpinan Tingkat IV yang memperoleh kualifikasi tidak memuaskan dinyatakan Tidak Lulus dan peserta Pelatihan Kepemimpinan Tingkat IV yang memperoleh kualifikasi kurang memuaskan dinyatakan ditunda kelulusannya dan kepada yang bersangkutan diberikan waktu maksimal 60 hari kalender untuk menyempurnakan proyek perubahannya.

Dari hasil analisis kuesioner Evaluasi Kepemimpinan oleh peserta, dimana peserta diminta untuk menceritakan pengalaman nya selama mengikuti Pelatihan Kepemimpinan Tingkat IV, maka didapatlah level learning dari Pelatihan Kepemimpinan Tingkat IV ini. Pengalaman yang ditulis peserta dapat dijadikan salah satu acuan dalam mengevaluasi proses pembelajaran, dalam hal penguasaan peserta terhadap materi pelatihan. Salah seorang peserta menulis 'Dengan mengikuti pelatihan kepemimpinan 
pola baru saya merasakan ada perubahan terhadap pola pandang, pola pikir dan pola perilaku ke arah lebih baik'. Pengalaman yang dituliskan oleh peserta ini menyiratkan bahwa proses pembelajaran dalam Pelatihan Kepemimpinan Tingkat ini telah bisa mengubah pola pandang, pola pikir dan pola perilaku peserta. Selama mengikuti pembelajaran pada Pelatihan Kepemimpinan Tingkat, peserta dapat merasakan manfaat bagi dirinya.

Salah satu agenda dalam kurikulum Pelatihan Kepemimpinan Tingkat IV adalah Agenda Inovasi dengan mata pelatihannya Berpikir Kreatif dan Inovasi, Pengenalan Potensi Diri, dan Benchmarking to Best Practice. Berikut beberapa catatan peserta terhadap agenda inovasi ini:

Di dalam pelatihan kepemimpinan pola baru ini, kami banyak mendapatkan ilmu yang bermanfaat bagi saya dan untuk diterapkan di dinas instansi saya, yang selama ini di instansi saya belum ada inovasi, Insya Allah dengan selesainya pelatihan ini, maka saya bisa meneruskan implementasi proyek perubahan ini, di jangka menengah dan jangka panjang.

Inovasi perubahan yang didapat melalui pelatihan dan pembelajaran di pelatihan memmberikan manfaat untuk solusi tupoksi yang diemban saat ini. Dalam mengikuti Pelatihan PIM Tingkat IV ini, saya dapat berpikir kreatif dan inovatif sehingga dapat diimplementasikan dalam instansi temopat saya bertugass dalam sebuah organisasi.

Pengalaman pengalaman yang ditulis peserta tersebut menunjukkan bahwa proses pembelajaran di Agenda Inovasi sudah berhasil mengubah pola pikir peserta tentang inovasi.

Salah seorang peserta juga menulis tentang proses pembelajaran di Pelatihan Kepemimpinan Tingkat IV ini. Menurut dia 'Proses pembelajaraan dengan pola kreatif, berpikir dan banyak studi studi kasus, kerja sama dalam tim'. Widyaiswara dalam Pelatihan Kepemimpinan Tingkat IV ini telah menggunakan berbagai macam metode dalam proses pembelajaran sehingga tujuan pembelajaran yang telah dirumuskan sebelumnya dapat tercapai.

Selanjutnya, level learning ini juga dianalisis melalui studi dokumentasi yaitu nilai yang didapat peserta sebagai gambaran dari keberhasilan pembelajaran selama Pelatihan Kepemimpinan Tingkat IV angkatan $\mathrm{V}$. Keberhasilan peserta mengikuti Pelatihan Kepemimpinan Tingkat IV dilihat dari kemampuan mereka menyusun proyek perubahan. Penilaian proyek perubahan ini dilaksanakan dua kali yaitu dalam Seminar Rancangan Proyek Perubahan dan Seminar Laboratorium Kepemimpinan.

Dari hasil analisis nilai Seminar Rancangan Proyek Perubahan diketahuilah bahwa para peserta masih lemah dalam penentuan jenis perubahan karena nilai rata ratanya terendah. Dalam rubrik penilaian penentuan jenis perubahan, nilai rata-rata 77,4 masuk ke dalam level 3 yaitu Sebagian Gagasannya Baru. Jenis perubahan yang diajukan peserta bukan merupakan gagasan baru sama sekali akan tetapi merupakan adaptasi dari gagasan yang sudah ada sebelumnya.

Dari rekapitulasi nilai Seminar Laboratorium Kepemimpinan, unsur penilaian yang mempunyai rata rata terendah adalah Pernyataan Dukungan. Hal ini berarti bahwa tidak semua pemangku kepentingan (stakeholder) yang dimasukkan peserta dalam proyek perubahan mereka mendukung saat implementasi proyek perubahan tersebut.

Nilai akhir sebagai penentuan kelulusan peserta merupakan gabungan dari nilai seminar Rancangan Proyek Perubahan dan nilai Seminar Laboratorium Kepemimpinan. Dari rekapitulasi kedua nilai tersebut maka didapatlah kualifikasi kelulusan peserta. Adapun persentase kelulusan peserta Pelatihan Kepemimpinan Tingkat IV angkatan V berdasarkan kualifikasi kelulusan adalah 2,5\% Sangat Memuaskan, 42,5\% Memuaskan, 50\% Cukup Memuaskan, 2,5\% Kurang Memuaskan, 2,5\% Tidak Memuaskan/Tidak Lulus. Penyebaran persentase kualifikasi kelulusan ini merata artinya tidak menumpuk di kualifikasi teratas dan juga tidak menumpuk di kualifikasi 
terendah, akan tetapi kebanyakan berada di kualifikasi kelulusan di tengah. Hal ini mengindikasikan bahwa proses pembelajaran dalam pelaksanaan Pelatihan Kepemimpinan Tingkat IV angakatan V ini sudah baik.

\section{Behavior}

Behavior dari peserta pelatihan dievaluasi setelah beberapa bulan mereka selesai mengikuti Pelatihanpin IV. Instrumen yang digunakan adalah kuesioner evaluasi pasca pelatihan seperti yang terlampir dalam Peraturan kepala Lembaga Administrasi Negara RI Nomor 20 Tahun 2015.

Tabel 1

Persentase Per-opsi dalam Instrumen Kuesioner Pasca Pelatihan

\begin{tabular}{|c|c|c|c|c|c|c|}
\hline \multirow{2}{*}{$\begin{array}{c}\text { No } \\
\text { Urut }\end{array}$} & \multirow{2}{*}{$\begin{array}{l}\text { Kode } \\
\text { Item }\end{array}$} & \multicolumn{5}{|c|}{ Persentase Per-opsi } \\
\hline & & 1 & 2 & 3 & 4 & 5 \\
\hline 1. & A1 & 8,8 & 23,5 & 38,2 & 29,4 & \\
\hline 2. & $\mathrm{~A} 2$ & 23,5 & 32,4 & 5,9 & 8,8 & 29,4 \\
\hline 3. & A3 & 52,9 & 29,4 & 17,6 & & \\
\hline 4. & A5 & 20,6 & 26,5 & 35,3 & 17,6 & \\
\hline 5. & A6 & 47,1 & 35,3 & 17,6 & & \\
\hline 6. & A7 & 41,2 & 47,1 & 11,8 & & \\
\hline 7. & A8 & 44,1 & 41,2 & 14,7 & & \\
\hline 8. & A9 & 38,2 & 52,9 & 8,8 & & \\
\hline 9. & B1 & 58,8 & 29,4 & 11,8 & & \\
\hline 10. & B3 & 52,9 & 41,2 & 5,9 & & \\
\hline 11. & B5 & 94,1 & 5,9 & & & \\
\hline
\end{tabular}

Item dengan kode A4, A10, B2, B4, dan B6 merupakan item kuesioner pertanyaan terbuka dimana responden menuliskan jawabannya dengan bebas. Berikut adalah sampel jawaban responden:

Tabel 2

Sampel Jawaban Responden dari Kuesioner Diisi Mentor

\begin{tabular}{|c|c|l|}
\hline No & $\begin{array}{c}\text { Kode } \\
\text { Item }\end{array}$ & \multicolumn{1}{c|}{ Jawaban Responden (sampel) } \\
\hline 1. & A4 & $\begin{array}{l}\text { Adanya kemudahan dalam memberikan pelayanan kepada } \\
\text { publik }\end{array}$ \\
\hline 2. & A10 & Agar proyek perubahan ini tetap melakukan inovasi terbaik \\
\hline 3. & B2 & $\begin{array}{l}\text { a. Mampu membangun kerjasama yang baik dengan atasan } \\
\text { dan dengan bawahan } \\
\text { b. Alumni menunjukkan perilaku diplin dalam bekerja } \\
\text { c. Adanya peningkatan sikap dan perilaku alumni dalam } \\
\text { berkoordinasi dengan pemangku kepentingan }\end{array}$ \\
\hline 4. & B4 & $\begin{array}{l}\text { a. Kegiatan administrasi berjalan dengan lancar } \\
\text { bemampuan alumni dalam mejalin hubungan dengan } \\
\text { atasan bertambah lebih terampil } \\
\text { c. Muncul nya ide ide dari alumni tentang inovasi pelayanan } \\
\text { di instansi }\end{array}$ \\
\hline 5. & B6 & $\begin{array}{l}\text { a. Adanya pelayanan yang cepat, tepat, efektif dan efisien } \\
\text { b. Adanya perubahan perilaku petugas pelayanan } \\
\text { c. Kemudahan dalam melaksanakan tugas tugas rutin kantor }\end{array}$ \\
\hline
\end{tabular}

Hasil dari analisis kuesioner evaluasi pasca Pelatihan Kepemimpinan Tingkat tingkat IV yang diisi oleh atasan langsung peserta atau mentor saat mereka mengikuti Pelatihan Kepemimpinan Tingkat IV menunjukkan bahwa ada perubahan perilaku peserta setelah mengikuti Pelatihan Kepemimpinan Tingkat IV. Lebih dari $50 \%$ Mentor menyatakan sangat setuju bahwa setelah mengikuti Pelatihan Kepemimpinan Tingkat Tingkat IV, perilaku kerja alumni yang mereka mentori menunjukkan perubahan ke arah yang lebih baik dan Setelah mengikuti Pelatihan Kepemimpinan Tingkat Tingkat IV, kinerja alumni yang mereka mentori mengalami peningkatan dan lebih dari $90 \%$ mentor berpendapat bahwa peningkatan kinerja alumni tersebut meningkatkan kinerja organisasi. Para mentor juga berpendapat bahwa kemampuan koordinasi alumni Pelatihan kepada atasan (selaku mentor) dalam merealisasikan proyek perubahan sudah sangat baik. Kemampuan kepemimpinan yang dilakukan oleh alumni Pelatihan dalam merealisasikan proyek perubahan juga sangat baik dan kemampuan kerja sama dengan tim pada alumni menurut mentor juga sangat baik.

Hal ini menunjukkan bahwa Pelatihan Kepemimpinan Tingkat IV angkatan $\mathrm{V}$ tahun 2018 ini telah membawa perubahan prilaku alumninya dalam hal peningkatan kinerja, kemampuan koordinasi, kemampuan kepemimpinan, dan kemampuan kerjasama dalam tim. Perilaku alumni yang diamati oleh mentor adalah adanya perubahan dalam memberikan pelayanan kepada masyarakat dan juga alumni mulai memunculkan ide ide baru dalam inovasi pelayanan di instansi nya. Hasil penelitian ini mendukung pernyataan Siagian (1995) yang menyatakan bahwa pentingnya pendidikan dan pelatihan sebagai salah satu investasi dalam bidang sumber daya manusia (Human Investment) yang harus dilaksanakan oleh setiap organisasi, apabila organisasi yang bersangkutan ingin bukan saja meningkatkan efisiensi dan efektivitas kinerjanya, akan tetapi dalam rangka mempercepat, pemantapan perwujudan perilaku organisasi yang diinginkan".

\section{Result}

Kuesioner evaluasi pasca pelatihan yang diisi oleh peserta sebagai alumni Pelatihan 
Kepemimpinan Tingkat IV angkatan $V$ menunjukkan bahwa kendala utama yang menghambat pencapaian proyek perubahan mereka adalah kurang dukungan dana dan sumber daya lain. Sedangkan faktor utama yang mendukung pelaksanaan pproyek perubahan mereka adalah proyek perubahan dijadikan kegiatan rutin dalam menunjang tugas dan fungsi. Pihak mana yang paling merasakan manfaat dan proyek perubahan yang mereka lakukan adalah organisasi secara umum.

Kebanyakan alumni berpendapat bahwa materi yang diperoleh selama Pelatihan Kepemimpinan Tingkat Tingkat IV, dapat menunjang mereka dalam mengimplementasikan proyek perubahan. Dan agenda yang menurut mereka perlu lebih dalami pada saat pelatihan adalah Agenda Diagnosa Perubahan. Mereka juga berpendapat adanya proyek perubahan pada Pelatihan Kepemimpinan Tingkat IV sangat baik.

Setelah mengikuti Pelatihan Kepemimpinan Tingkat Tingkat IV, para alumni mengalami perubahan perilaku kerja ke arah yang lebih baik. Perilaku yang mereka tinggalkan sebagai bentuk dampak pelaksanaan Pelatihan adalah bekerja sendiri tanpa melibatkan orang lain. Mereka sangat setuju jika kinerja mereka meningkat sebagai dampak mengikuti Pelatihan Kepemimpinan Tingkat Tingkat IV. Peningkatan kinerja mereka ini juga berdampak positif terhadap peningkatan kinerja organisasi

\section{KESIMPULAN}

\section{Kesimpulan}

Pada level Reaction, peserta Pelatihan Kepemimpinan Tingkat IV angkatan $V$ tahun 2018 telah menunjukkan reaksi positif terhadap widyaiswara dan juga coach. Sedangkan reaksi mereka terhadap pelaksanaan pelatihan cukup baik pada item relavansi, namun pada item konsumsi, mereka menunjukkan reaksi yang sangat kurang. Reaksi tim evaluasi terhadap widyaiswara sudah sangat memuaskan, tapi masih perlu perbaikan pada item menulis karya tulis ilmiah di bidang kepelatihanan.
Dalam level Learning didapat bahwa proses pembelajaran di Pelatihan Kepemimpinan Tingkat IV angkatan $\mathrm{V}$ sudah menunjukkan keberhasilan dari sebaran nilai kelulusan pesertanya yang memperlihatkan bahwa $50 \%$ peserta lulus dengan kualifikasi memuaskan. Selebihnya masuk ke kualifikasi yang lain yang tersebar secara merata.

Level Behavior menunjukkan bahwa ada perubahan perilaku alumni Pelatihan Kepemimpinan Tingkat IV angkatan $V$ sesudah mengikuti Pelatihan. Perubahan perilaku ini mencakup kinerja, koordinasi dengan atasan, kepemimpinan, dan kerja sama dengan tim.

Pada level Result, alumni berpendapat bahwa materi yang mereka dapatkan saat mengikuti pelatihan dapat menunjang implementasi proyek perubahan dalam jangka menengah dan jangka panjang. Akan tetapi implementasi proyek perubahan ini terkendala dari kurangnya dukungan dana dan sumber daya lain yang ada.

\section{Saran}

Dari simpulan di atas maka ada beberapa rekomendasi terhadap penyelenggaraan Pelatihanpim IV sebagai berikut:
1. Agar para
tenaga pengajar/widyaiswara lebih dioptimalkan lagi pemberdayaan nya sehingga dapat memberikan pelayanan yang maksimal dalam proses pembelajaran di kelas dan juga dalam pendampingan penulisan proyek perubahan peserta.

2. Perlu perbaikan pada pemberian pelayanan kepada peserta Pelatihanpim IV, terutama dalam hal pengaturan konsumsi peserta karena akan berdampak juga pada keberhasilan peserta nantinya saat mengikuti pelatihan.

Pelaksanaan evaluasi pasca pelatihan tetap terus dilaksanakan sebagai salah satu indikator keberhasilan pelaksanaan pelatihan (result). Melalui evaluasi pasca pelatihan dapat diketahui bagaimana perilaku (behavior) alumni pelatihan di tempat kerja nya masingmasing. 


\section{REFERENSI}

Ananda, R., \& Tien, R. 2017. Pengantar Evaluasi Program Pendidikan. Medan: Perdana Publishing.

Andriani, S., Kesumawati, N., \& Kristiawan, M. 2018. The Influence of the Transformational Leadership and Work Motivation on Teachers Performance. International Journal of Scientific \& Technology Research, 7(7).

Badu, Q., S. 2013. The Implementation of Kirkpatrick's Evaluation Model in the Learning of Initial Value and Boundary Condition Problems. International Journal of Learning and Development. ISSN 2164-4063. 2013. Vol.3, No.5.

Fathurrochman, I., Budiman, D. A., Alamsyahril, \& Kristiawan, M. 2019. Revitalization Management Of Islamic Boarding School Preventing The Radicalism. Restaurant Business, (10), 495-505. Retrieved from https://journals.eduindex.org/index.php /rb/article/view/9462.

Fitria, H., Kristiawan, M., \& Rasyid, A. 2019. The Educational Character on Instruction. Opción, Año 35, Especial No.21 (2019): 964-979

Kirkpatrick, D., L. \& Kirkpatrick J., D. 2006. Evaluating Training Program The Four Levels. San Fransisco : Berret-Kohler Publisher, Inc.

Maseleno, A., Ayshwary, B., Ivanova, T. N., Hashim, W., Nguyen, P. T., Shankar, K., Kristiawan, M., Huda, M. 2019. General Theoretical and Philosophical Aspects of Modern Education. Aspectos Teóricos y Filosóficos Generales de la Educación Moderna. Revista San Gregorio 2019, No. 32 Special Issues August.

Mulyatiningsih, E. 2014. Metode Penelitian Terapan Bidang Pendidikan. Bandung: Alfabeta

Pemerintah Republik Indonesia. 2014. Undang Undang Nomor 5 Tahun 2014 tentang Aparatur Sipil Negara.

Peraturan Kepala Lembaga Administrasi Negara Nomor 20 Tahun 2015 Tentang Pedoman Penyelenggaraan Pendidikan Dan Pelatihan Kepemimpinan Tingkat IV.

Peraturan Pemerintah Nomor 101 Tahun 2000 tentang Pendidikan dan Pelatihan Pegawai Negeri Sipil (PNS).

Peraturan Menteri Pendayagunaan Aparatur Negara dan Reformasi Birokrasi Republik Indonesia Nomor 22 Tahun 2014 Tentang Jabatan Fungsional Lecturer Dan Angka Kreditnya.

Purwanto \& Atwi Suparman. 1999. Evaluasi Program Pelatihan. Jakarta: Sekolah Tinggi Ilmu Administrasi, Lembaga Administrasi Negara.

Ramadhon, Syafril. 2018. Penerapan Model Empat Level Kirkpatrick Dalam evaluasi Program Pendidikan Dan Pelatihan Aparatur di Puspelatihan Migas. Forum Pelatihan. 06 (1).43-54

Rouse, D. 2011. Employing Kirkpatrick's Evaluation Framework to Determine the Effectiveness of Health Information Management Courses and Program. Perspectives in Health Information Management, Spring 2011.

Siagian. 2002. Sumber Daya Manusia. Jakarta: PT. Ranika Cipta 